\title{
On the relationship between acetone and carbon monoxide in different air masses
}

\author{
M. de Reus ${ }^{1}$, H. Fischer ${ }^{1}$, F. Arnold ${ }^{3}$, J. de Gouw ${ }^{2}$, R. Holzinger ${ }^{1}$, C. Warneke ${ }^{2}$, and J. Williams ${ }^{1}$ \\ ${ }^{1}$ Max Planck Institute for Chemistry, Airchemistry Department, Mainz, Germany \\ ${ }^{2}$ National Oceanic and Atmospheric Administration (NOAA), Aeronomy Laboratory, Boulder, USA \\ ${ }^{3}$ Max Planck Institute for Nuclear Physics, Atmospheric Physics Division, Heidelberg, Germany
}

Received: 18 December 2002 - Published in Atmos. Chem. Phys. Discuss.: 21 February 2003

Revised: 2 October 2003 - Accepted: 6 October 2003 - Published: 14 October 2003

\begin{abstract}
Carbon monoxide and acetone measurements are presented for five aircraft measurement campaigns at midlatitudes, polar and tropical regions in the northern hemisphere. Throughout all campaigns, free tropospheric air masses, which were influenced by anthropogenic emissions, showed a similar linear relation between acetone and $\mathrm{CO}$, with a slope of 21-25 $\mathrm{ppt}_{\mathrm{v}}$ acetone/ppb $\mathrm{VO}$. Measurements in the anthropogenically influenced marine boundary layer revealed a slope of 13-16 $\mathrm{ppt}_{\mathrm{v}}$ acetone/ppb $\mathrm{VO}$. The different slopes observed in the marine boundary layer and the free troposphere indicate that acetone is emitted by the ocean in relatively clean air masses and taken up by the ocean in polluted air masses. In the lowermost stratosphere, a good correlation between acetone and $\mathrm{CO}$ was observed as well, however, with a much smaller slope $\left(\sim 5 \mathrm{ppt}_{\mathrm{v}}\right.$ acetone/ppb $\left.\mathrm{v}_{\mathrm{v}} \mathrm{CO}\right)$ compared to the troposphere. This is caused by the longer photochemical lifetime of $\mathrm{CO}$ compared to acetone in the lower stratosphere, due to the increasing photolytic loss of acetone and the decreasing $\mathrm{OH}$ concentration with altitude. No significant correlation between acetone and $\mathrm{CO}$ was observed over the tropical rain forest due to the large direct and indirect biogenic emissions of acetone.

The common slopes of the linear acetone-CO relation in various layers of the atmosphere, during five field experiments, makes them useful for model calculations. Often a single observation of the acetone-CO correlation, determined from stratospheric measurements, has been used in box model applications. This study shows that different slopes have to be considered for marine boundary layer, free tropospheric and stratospheric air masses, and that the acetone-CO relation cannot be used for air masses which are strongly influenced by biogenic emissions.
\end{abstract}

Correspondence to: $\mathrm{M}$. de Reus

(reus@mpch-mainz.mpg.de)

\section{Introduction}

Acetone $\left(\mathrm{CH}_{3} \mathrm{COCH}_{3}\right)$ is one of the most abundant partially oxidised hydrocarbons $(\mathrm{POH})$ in the atmosphere. Its background mixing ratio ranges between $200 \mathrm{ppt}_{\mathrm{v}}$ in the southern hemisphere and $500 \mathrm{ppt}_{\mathrm{v}}$ in the northern hemisphere (Singh et al., 1995). However, mixing ratios exceeding $2 \mathrm{ppb}_{\mathrm{v}}$ in the free troposphere and $1 \mathrm{ppb}_{\mathrm{v}}$ in the lower stratosphere have been observed (Wohlfrom et al., 1999; Arnold et al., 1997; Pöschl et al., 2001). The major anthropogenic sources of acetone in the atmosphere are direct emissions and secondary production by the oxidation of hydrocarbons (i.e. propane, isobutane and isopentane). Biogenic sources include direct emissions from vegetation, decaying organic material and secondary production by the oxidation of biogenic hydrocarbons (e.g. monoterpenes). Moreover, biomass burning provides a source of acetone in the atmosphere (Singh et al., 1994; Jacob et al., 2002). Acetone is removed from the atmosphere by photolysis, the reaction with $\mathrm{OH}$ radicals and wet and dry deposition (Singh et al., 1994; Jacob et al., 2002).

The exchange of acetone with the ocean also plays an important role in the acetone budget. For the global acetone budget, the ocean has to be considered as a source of acetone, however, oceans provide both a photochemical source and a microbial sink of acetone, depending on the geographical region (Jacob et al., 2002). The uptake of acetone by the ocean in areas of upwelling water has been observed over the northwest Indian Ocean by Warneke and de Gouw (2001). Model calculations for the northern Indian Ocean region show an overestimation of acetone in polluted air masses (de Laat et al., 2001), which also points towards the uptake of acetone by the ocean. However, in relatively clean air $\left(\mathrm{CO}<100 \mathrm{ppb}_{\mathrm{v}}\right)$, the acetone concentration was underestimated by the model and a marine acetone source had to be included to reproduce the acetone measurements (de Laat et al., 2001; Wisthaler et al., 2002). 
In the presence of $\mathrm{NO}_{\mathrm{x}}$, the photochemical breakdown of acetone produces peroxyacetylnitrate (PAN), a relatively unreactive reservoir species for $\mathrm{NO}_{\mathrm{x}}$ in the upper free troposphere. Furthermore, acetone can provide substantial amounts of $\mathrm{OH}$ and $\mathrm{HO}_{2}$ radicals in the free troposphere that may contribute to ozone production (Singh et al., 1995; McKeen et al., 1997). A good correlation has been observed between carbon monoxide and acetone mixing ratios during several field studies (Singh et al., 1994; Mauzerall et al., 1998; Reiner et al., 2001), which points to common sources of $\mathrm{CO}$ and acetone. $\mathrm{CO}$ is a well known tracer for anthropogenic pollution and biomass burning, since it is produced by incomplete combustion processes. Moreover, $\mathrm{CO}$ is mostly co-emitted with a large number of different hydrocarbons, and is, therefore, also related to the secondary production of acetone.

Since acetone is an important molecule in the chemistry of the atmosphere, it should be considered in model calculations. In global models, emissions of acetone are mostly explicitly described, whereas in box model studies the model is generally constrained to measurements. Since acetone measurements are not always available, the correlation between acetone and $\mathrm{CO}$ is often used for model initialisation (McKeen et al., 1997; Keim et al., 1999; Frost et al., 2002).

This paper deals with the acetone-CO correlation observed during different aircraft measurement campaigns. A common linear correlation is defined for various air masses, which could be used in future model calculations.

\section{Experiments and instrumentation}

In this paper carbon monoxide and acetone measurements during different airborne measurement campaigns are presented. A short description of the measurement campaigns and applied instruments is given below. The Mediterranean Intensive Oxidant Study, MINOS, took place in August 2001 from Crete, Greece. The main goal of the measurements was to determine anthropogenic pollution transport over the Mediterranean. Airborne measurements were performed on the Falcon aircraft, operated by the German Aerospace Centre (DLR) (Lelieveld et al., 2002). The other campaigns, presented below, have been performed using a Cessna Citation aircraft, operated by the Technical University Delft, the Netherlands. Both aircraft have a vertical range of $12-13 \mathrm{~km}$.

The Indian Ocean Experiment, INDOEX, was carried out in February and March 1999 from the Maldives. It focussed on the transport of anthropogenic pollutants, originating from south and southeast Asia, over the northern Indian Ocean (Lelieveld et al., 2001).

The Cooperative LBA (Large-scale Biosphere-atmosphere experiment in Amazonia) Airborne Regional Experiment, LBA-CLAIRE, was organised to study biogenic emissions from the tropical rain forest. Therefore, research flights were performed over the Amazon rain forest from Paramaribo, Surinam, in March 1998 (Crutzen et al., 2000).

Moreover, data from two STREAM (Stratosphere Troposphere Experiment by Aircraft Measurements) campaigns are included, STREAM98 and STREAM97. The STREAM98 campaign focussed on long range transport of biomass burning emissions and was performed from Timmins, Canada, in July 1998 (Fischer et al., 2002). STREAM97 focussed on ozone depletion in the spring Arctic lowermost stratosphere and took place in March 1997 from Kiruna, Sweden (Fischer et al., 2000).

During all campaigns, carbon monoxide was measured using a tunable diode laser absorption spectrometer (TDLAS). This instrument is optimised for airborne measurements and is described in detail by Wienhold et al. (1998) and Kormann et al. (2002). In-situ calibrations have been performed during all flights against working standards consisting of compressed air. These were cross-calibrated before and after the campaigns against National Oceanic and Atmospheric Administration (NOAA) standards using gas chromatography. The accuracy and precision of the CO measurements for the various measurement campaigns are given in Table 1.

Acetone measurements were performed using a protontransfer-reaction mass spectrometer (PTR-MS) and a chemical ionisation mass spectrometer (CIMS). In both instruments, acetone is chemically ionised by the proton transfer with $\mathrm{H}_{3} \mathrm{O}^{+}$ions and the products are detected with a quadrupole mass spectrometer (Lindinger et al., 1998; Möhler et al., 1993). The CIMS instrument has been used during both STREAM campaigns, the PTR-MS instrument throughout the other campaigns. No in-flight calibrations were performed for the acetone measurements. The sensitivity of the CIMS instrument during STREAM97 and STREAM98 and the PTR-MS instrument during LBACLAIRE has been calculated from the rate constant of the reaction of acetone with $\mathrm{H}_{3} \mathrm{O}^{+}$ions and the reaction time. The sensitivity of the PTR-MS has been tested in the laboratory after the LBA-CLAIRE campaign, resulting in an accuracy of 30\% (Warneke et al., 2001). During INDOEX and MINOS, the PTR-MS instrument was calibrated prior to and after the campaign using a standard mixture containing a number of volatile organic compounds (VOCs) in $\mathrm{N}_{2}$ (de Gouw et al., 2001). During MINOS, an additional calibration was performed in the field. In-flight background measurements were performed for the PTR-MS on a regular basis by passing the sample air through a charcoal filter (LBA-CLAIRE and INDOEX) or a thermal platinum converter (MINOS). This background has been subtracted from the measured signal to obtain the atmospheric mixing ratio.

At high ambient water vapour mixing ratios, occurring in the boundary layer and lower free troposphere, the reverse reaction of the protonated acetone complex in the flow tube of the CIMS instrument becomes important, leading to an underestimation of the observed acetone mixing ratio. A correction for this reverse reaction has been applied to the 
Table 1. Measurement technique, accuracy of the standard used for the calibration of the instrument, precision and responsible institutes for the $\mathrm{CO}$ and acetone measurements during the measurement campaigns presented in this study

\begin{tabular}{lccclcc}
\hline Campaign & CO & accuracy of standard & precision & Acetone & accuracyof standard & precision \\
\hline STREAM97 & TDLAS $^{1}$ & $1 \%$ & $2 \%$ & CIMS $^{2}$ & $40 \%$ & $10 \%$ \\
LBA-CLAIRE & TDLAS $^{1}$ & $3 \%$ & $2 \%$ & PTRMS $^{3}$ & $30 \%$ & $20 \%$ \\
STREAM98 & TDLAS $^{1}$ & $1.3 \%$ & $2.5 \%$ & CIMS $^{2}$ & $30 \%$ & $20-40 \% *$ \\
INDOEX & TDLAS $^{1}$ & $10 \%$ & $10 \%$ & PTRMS $^{4}$ & $20 \%$ & $20 \%$ \\
MINOS & TDLAS $^{1}$ & $1 \%$ & 1.5 ppbv & PTRMS $^{4}$ & $20 \%$ & $20 \%$ \\
\hline
\end{tabular}

* precision dependent on the $\mathrm{H}_{2} \mathrm{O}$ partial pressure, we used $20 \%$ for the stratospheric measurements and $40 \%$ for the tropospheric measurements.

Measurements performed by the:

${ }^{1}$ Max Planck Institute for Chemistry, Mainz, Germany.

${ }^{2}$ Max Planck Institute for Nuclear Physics, Heidelberg, Germany.

${ }^{3}$ University of Innsbruck, Austria.

${ }^{4}$ Institute for Marine and Atmospheric Research Utrecht, The Netherlands.

STREAM98 data using the simultaneous measured acetonitrile mixing ratio (Wohlfrom et al., 1999). This reverse reaction did not play a significant role in STREAM97, since the measurements were mainly performed in the stratosphere, where the water vapour mixing ratio was very low (Schneider, 1997). No significant dependence of the PTR-MS acetone measurements on ambient relative humidity was found in laboratory studies (Warneke et al., 2001). The accuracy, precision and the institutes responsible for the acetone measurements during the different campaigns are listed in Table 1 .

The different techniques to measure acetone in the atmosphere have been compared during several measurement campaigns. Sprung et al. (2001) describe an intercomparison between the acetone measurements using a CIMS and a PTR-MS instrument, which were deployed on the C130 aircraft during INDOEX. They found that the PTR-MS showed slightly higher acetone mixing ratios than the CIMS. The agreement between the two instruments was within $20 \%$, which is smaller than the accuracy of each individual instrument. An intercomparison between two differently configured PTR-MS instruments, which were deployed on the Falcon aircraft during MINOS, shows excellent agreement in acetone mixing ratios measured by the two PTR-MS instruments (de Gouw et al., manuscript in preparation). Finally, acetone measurements performed with a CIMS instrument have been compared with those from an in-situ gas chromatograph (GC), which were flown on two different aircrafts during SONEX (Wohlfrom et al., 1999; Singh et al., 2000). The authors concluded that both data sets were consistent with each other within the uncertainty limits of the individual instruments, however, in the stratosphere the CIMS data tended to be higher than the GC by up to a factor 2 .

\section{Results}

In this section correlation plots of acetone and carbon monoxide are shown for various aircraft measurement campaigns. In all graphs, the carbon monoxide mixing ratio is plotted in $\mathrm{ppb}_{\mathrm{v}}$ on the $\mathrm{x}$-axis and acetone in $\mathrm{ppt}_{\mathrm{v}}$ on the $\mathrm{y}$ axis. Hence, the slope of the linear relation between acetone and $\mathrm{CO}$ is expressed in $\mathrm{ppt}_{\mathrm{v}}$ acetone/ppb $\mathrm{v}$ CO. A straight line fit, taking into account measurement errors in both coordinates, is used to determine the linear correlation between acetone and CO (Numerical recipes, Sect. 15.3) (Press et al., 1992). The measurement error or total uncertainty has been calculated by the square root of the sum of the squares of the precision and the calibration accuracy of the $\mathrm{CO}$ and acetone measurements as given in Table 1. Since this is a percentage of the measured concentration, the absolute measurement error (in $\mathrm{ppb}_{\mathrm{v}}$ or $_{\mathrm{ppt}}$ ) increases with increasing concentration, giving more weight to data points with lower concentrations in the linear fit. All data shown in this paper are $15 \mathrm{~s}$ averaged values.

Figure 1a shows the acetone and $\mathrm{CO}$ mixing ratios, observed during MINOS, including a linear fit through the data. The acetone and $\mathrm{CO}$ mixing ratios correlate very well, which is evident from the high linear correlation coefficient $\left(\mathrm{R}^{2}=0.81\right)$. The slope of the linear fit was $19.8 \mathrm{ppt}_{\mathrm{v}}$ acetone/ppb $\mathrm{pO}$.

Figures $1 \mathrm{~b}-\mathrm{d}$ show the acetone and $\mathrm{CO}$ mixing ratios for different subsets of the data, i.e. the marine boundary layer (b), free troposphere (c) and lowermost stratosphere (d). In the marine boundary layer $(0-1 \mathrm{~km}$ altitude) and the free troposphere $(1-12.5 \mathrm{~km})$ the correlation coefficient was high, indicating common sources for acetone and CO. The slope of the linear relation between acetone and $\mathrm{CO}$ was $13.5 \mathrm{ppt}_{\mathrm{v}}$ acetone/ppb $\mathrm{V} \mathrm{CO}$ in the marine boundary layer 

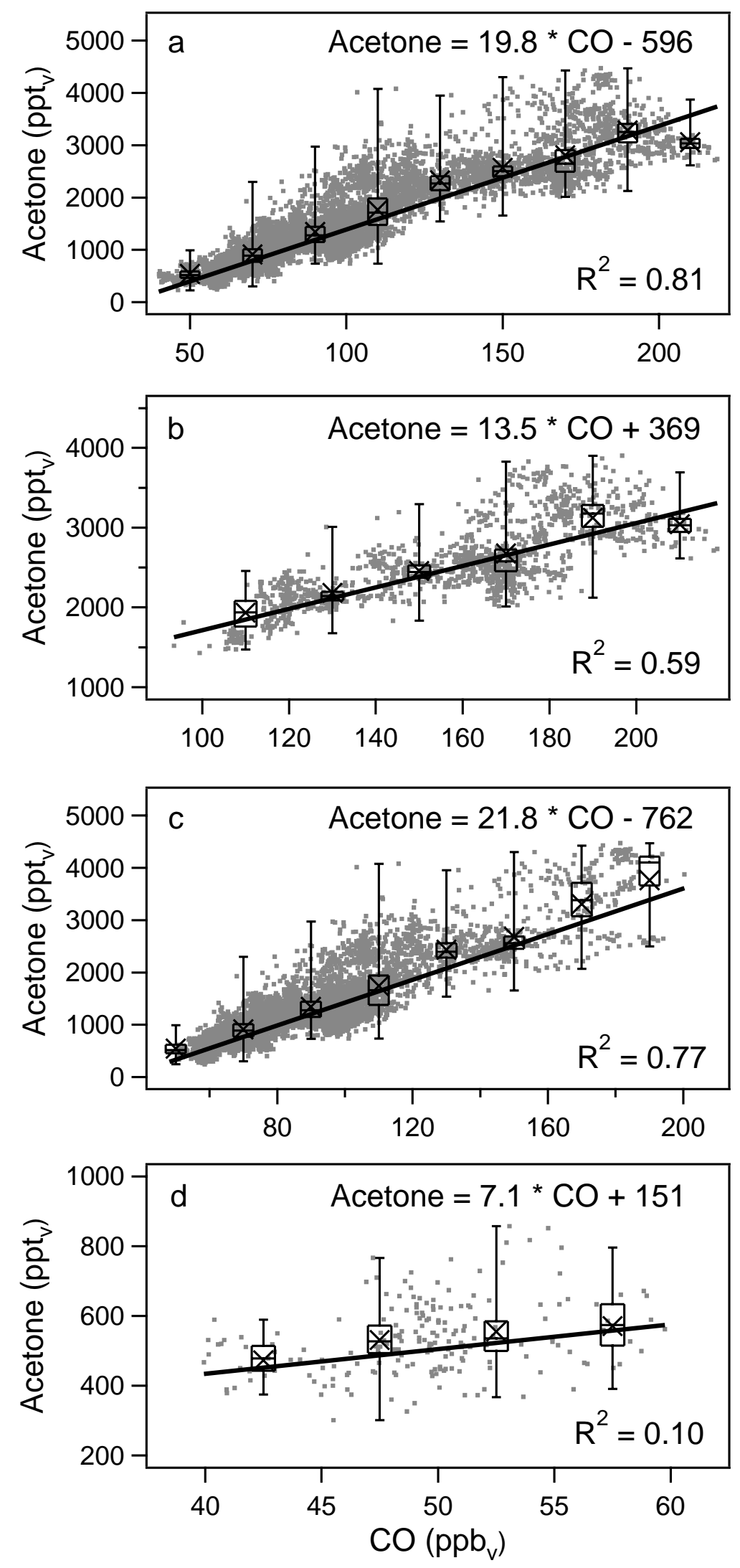

Fig. 1. Acetone and $\mathrm{CO}$ mixing ratios observed during the MINOS campaign (grey dots) and the linear correlation between the two trace gases (solid line). Figure (a) shows all data, (b) data from the marine boundary layer $(0-1 \mathrm{~km})$, (c) the free troposphere $(1-$ $12.5 \mathrm{~km})$ and (d) the lower stratosphere $\left(\mathrm{O}_{3}>150 \mathrm{ppb}_{\mathrm{v}} ; \mathrm{CO}<60 \mathrm{ppb}_{\mathrm{v}}\right)$. The boxes indicate the $33 \%$ and $67 \%$ percentiles, the whiskers the minimum and maximum value, the line the median and the cross the mean acetone mixing ratio for a certain $\mathrm{CO}$ interval. The slope and intercept $( \pm \sigma)$ of the correlations are presented in Table 2. 

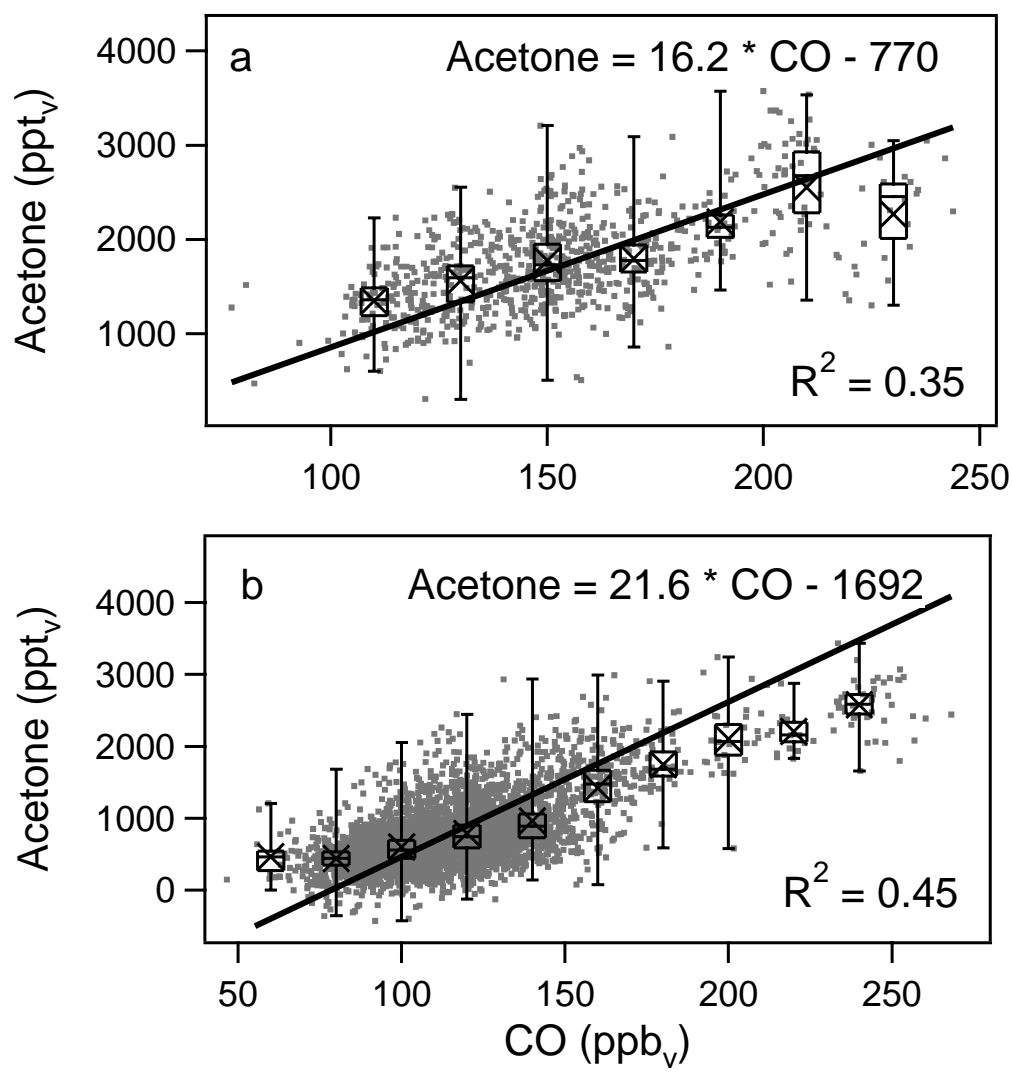

Fig. 2. Acetone and CO mixing ratios observed in the (a) marine boundary layer $(0-1 \mathrm{~km})$ and (b) free troposphere (1-12.5 km) during INDOEX.

$\left(\mathrm{R}^{2}=0.59\right)$ and 21.8 $\mathrm{ppt}_{\mathrm{v}}$ acetone/ppb $\mathrm{v} \mathrm{CO}$ in the free troposphere $\left(\mathrm{R}^{2}=0.77\right)$. The smaller slope in the marine boundary layer might reflect either the longer lifetime of acetone in the marine boundary layer compared to the free troposphere or an interaction with the ocean, which will be addressed in more detail in the discussion section.

On a few occasions stratospheric air masses were sampled, which were characterised by ozone mixing ratios above $150 \mathrm{ppb}_{\mathrm{v}}$ and $\mathrm{CO}$ mixing ratios below $60 \mathrm{ppb}_{\mathrm{v}}$. In the lowermost stratosphere, the slope of the linear correlation between acetone and $\mathrm{CO}$ was much lower than in the troposphere $\left(7.1 \mathrm{ppt}_{\mathrm{v}}\right.$ acetone/ppb $\left.\mathrm{V} \mathrm{CO}\right)$, which is caused by the absence of significant sources for $\mathrm{CO}$ and acetone in the stratosphere and the longer lifetime of $\mathrm{CO}$ compared to acetone, due to the increasing photolysis of acetone with altitude. The relatively low correlation coefficient $\left(R^{2}=0.10\right)$ is probably due to the limited amount of data points in the stratosphere and the poor precision of the acetone measurements due to the low mixing ratios.

Also during INDOEX, acetone and CO mixing ratios were very well correlated (see Fig. 2). Measurements have been performed in the marine boundary layer $(0-1 \mathrm{~km}$ altitude) and the free troposphere $(1-12.5 \mathrm{~km}$ altitude). The slope of the linear fit was $16.2 \mathrm{ppt}_{\mathrm{v}}$ acetone/ppb $\mathrm{VO}$ in the marine boundary layer $\left(\mathrm{R}^{2}=0.35\right)$ and $21.6 \mathrm{ppt}_{\mathrm{v}}$ acetone $/ \mathrm{ppb}_{\mathrm{v}} \mathrm{CO}$ in the free troposphere $\left(\mathrm{R}^{2}=0.45\right)$.

Both the INDOEX and MINOS campaigns were performed downwind of major anthropogenic pollution sources, which resulted in a highly polluted boundary layer (de Gouw et al., 2001; Lelieveld et al., 2002). Air masses observed in the marine boundary layer over the northern Indian Ocean during INDOEX originated from the Indian subcontinent and Southeast Asia. Numerous convective systems over the northern Indian Ocean caused the pollution from the marine boundary layer to be mixed up into the free troposphere (de Reus et al., 2001). De Gouw et al. (2001) determined the age of the pollution plumes observed during INDOEX using acetylene/ethane and benzene/ethane ratios. The age of the air masses observed in the marine boundary layer over the Indian Ocean ranged between 4 and 15 days. In the free troposphere similar air mass ages were found since convection lifted the relative fresh pollution from the marine boundary layer to the middle free troposphere.

During MINOS, anthropogenic pollution was observed in the marine boundary layer originating from eastern and western Europe. The air masses in the free troposphere over the Mediterranean were influenced by long range transport of pollutants from the US, Europe and Asia (Lelieveld et 

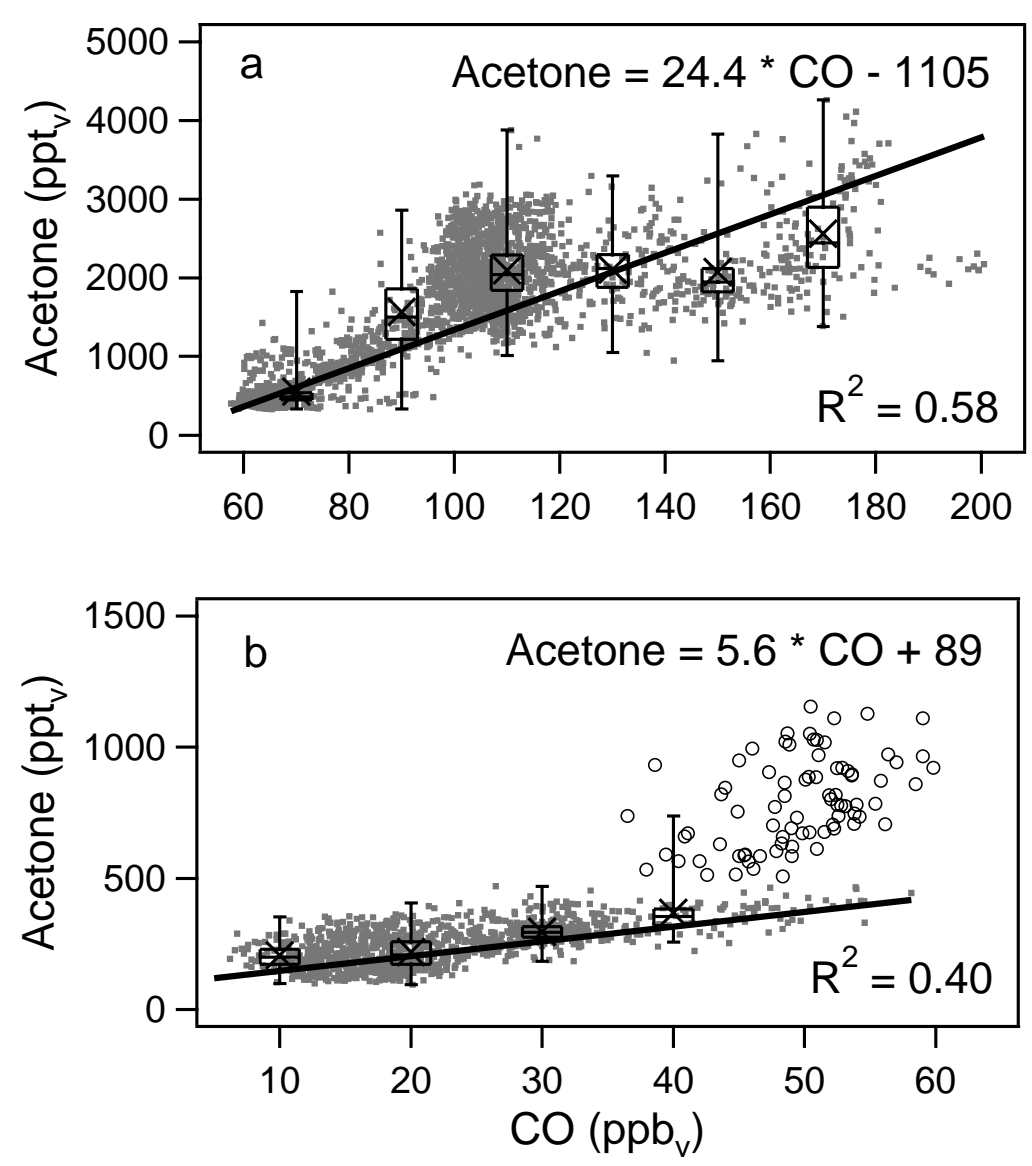

Fig. 3. Acetone and $\mathrm{CO}$ mixing ratios observed in the (a) free troposphere $(>7 \mathrm{~km})$ and (b) lower stratosphere $\left(\mathrm{O}_{3}>150 \mathrm{ppb}_{\mathrm{v}} ; \mathrm{CO}_{<} 60 \mathrm{ppb}_{\mathrm{v}}\right)$ during STREAM98. The open circles represent measurements which were strongly influenced by tropospheric mixing.

al., 2002; Traub et al., 2003). Salisbury et al. (2003) calculated the age of the air masses in the marine boundary layer using the toluene/benzene ratio from observations at the ground based station on Crete during the MINOS campaign and compared those with back trajectory calculations. They found that during the entire campaign the air mass age was below 30 hours. Since the aircraft performed its measurements north of the island of Crete, the air masses observed by the aircraft in the marine boundary layer have a maximum age of 30 hours. Scheeren et al. (2003) investigated the Southeast Asian air masses which dominated the free troposphere in the first half of the campaign. They determined a chemical age of these air masses of 7-15 days, based on the comparison of emission ratios from MINOS with emission ratios derived from INDOEX results and back trajectory calculations. The trajectory analysis also showed that North American pollution plumes were observed occasionally, which were lifted from below $700 \mathrm{hPa}$ between 5 and 10 days prior to the measurements. Moreover, recent convective injection of European boundary layer air was observed during two flights.
Hence, the air masses observed in the free troposphere over the Indian Ocean and the Mediterranean Sea were influenced by anthropogenic pollution and had a chemical age between a few days and 15 days. Apparently, within 15 days the signature of the linear relation between acetone and CO does not change significantly. In the free troposphere, the lifetime of acetone is shorter than the CO lifetime, due to the photolysis of acetone. In order to keep the acetone-CO relation stable over a time period of 15 days, secondary production of acetone has to compensate for the loss of acetone. This is further examined in the discussions section.

Although younger air masses were sampled in the marine boundary layer over the Mediterranean than over the northern Indian Ocean, a similar correlation between acetone and $\mathrm{CO}$ was observed. The major sources of CO over the northern Indian Ocean were biomass and biofuel burning (Lelieveld et al., 2001), whereas fossil fuel burning was the major source of $\mathrm{CO}$ in the marine boundary layer over the Mediterranean (Lelieveld et al., 2002). During STREAM98, measurements between 7 and $12.5 \mathrm{~km}$ altitude were performed. Air masses with ozone mixing ratios exceeding $150 \mathrm{ppb}_{\mathrm{v}}$ and $\mathrm{CO}$ mixing ratios below $60 \mathrm{ppb}_{\mathrm{v}}$ were considered to be stratospheric, 


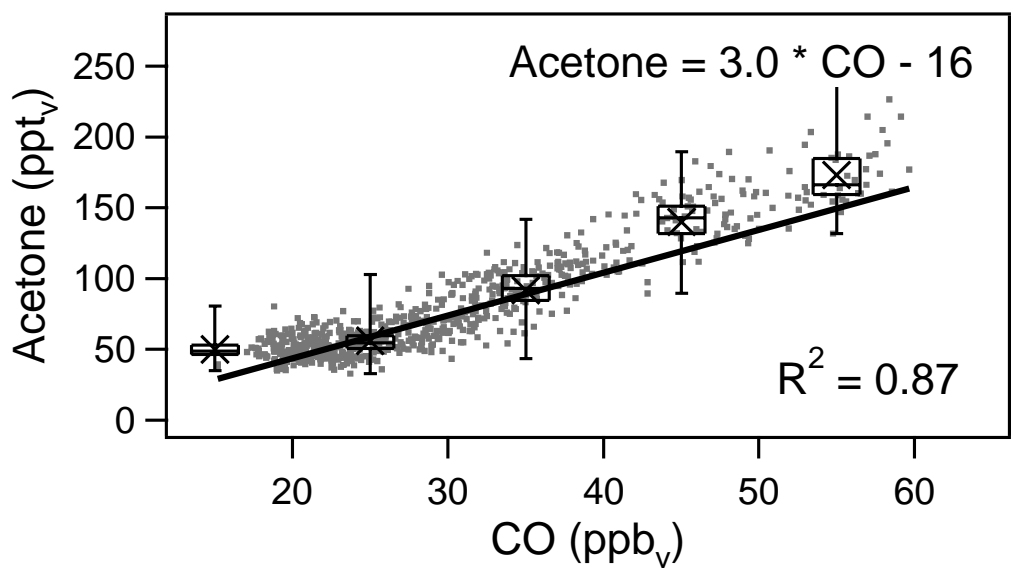

Fig. 4. Acetone and $\mathrm{CO}$ mixing ratios observed in the lower stratosphere $\left(\mathrm{O}_{3}>150 \mathrm{ppb}_{\mathrm{v}} ; \mathrm{CO}<60 \mathrm{ppb} \mathrm{v}_{\mathrm{v}}\right)$ during STREAM97.

Table 2. Slope (in $\mathrm{ppt}_{\mathrm{v}}$ acetone/ppb $\mathrm{V} \mathrm{CO} \pm 1 \sigma$ ) and intercept (in $\mathrm{ppt}_{\mathrm{v}}$ acetone $\pm 1 \sigma$ ) of the linear correlation between acetone and $\mathrm{CO}$ during different measurement campaigns

\begin{tabular}{llllll}
\hline Campaign & Operational base & Time period & Marine boundary layer & Free troposphere & Stratosphere \\
\hline STREAM97 & $\begin{array}{l}\text { Kiruna, } \\
\text { Sweden }\end{array}$ & March 1997 & - & - & $3.0 \pm 0.15$ \\
LBA-CLAIRE & $\begin{array}{l}\text { Paramaribo, } \\
\text { Surinam }\end{array}$ & March 1998 & No correlation & No correlation & $-16 \pm 3.8$ \\
\multirow{2}{*}{ STREAM98 } & $\begin{array}{l}\text { Timmins, } \\
\text { INDOEX }\end{array}$ & July 1998 & - & & \\
& Male, & Feb/Mar 1999 & $16.2 \pm 0.85$ & $-1105 \pm 34$ & $89 \pm 5.5$ \\
MINOS & Maldives & & $-770 \pm 120$ & $21.6 \pm 0.41$ & - \\
& Crete, & July 2001 & $13.5 \pm 0.70$ & $-1692 \pm 44$ & $7.1 \pm 2.5$ \\
& Greece & & $369 \pm 104$ & $21.8 \pm 0.22$ & $151 \pm 125$ \\
\hline
\end{tabular}

all other air masses tropospheric. The observed acetone and $\mathrm{CO}$ mixing ratios in the free troposphere and stratosphere are shown in Fig. 3. In both parts of the atmosphere acetone and $\mathrm{CO}$ were well correlated. The slope of the correlation was, however, very different. For the stratosphere a slope of $5.6 \mathrm{ppt}_{\mathrm{v}}$ acetone/ppb $\mathrm{v}_{\mathrm{v}} \mathrm{CO}$ was found $\left(\mathrm{R}^{2}=0.40\right)$, for the troposphere $24.4 \mathrm{ppt}_{\mathrm{v}}$ acetone/ppb $\mathrm{v} \mathrm{CO}\left(\mathrm{R}^{2}=0.58\right)$. During STREAM98 intensive mixing occurred between the lower stratosphere and the upper troposphere (Hoor et al., 2002). The open circles in Fig. 3b represent air masses with relatively high acetone mixing ratios which were observed at stratospheric $\mathrm{O}_{3}$ and $\mathrm{CO}$ mixing ratios. For these data points the linear relation between acetone and $\mathrm{CO}$ describes a slope of $17.3 \pm 8.2 \mathrm{ppt}_{\mathrm{v}}$ acetone/ppb $\mathrm{CO}\left(\mathrm{R}^{2}=0.23\right)$. Hence, these stratospheric air masses show a strong tropospheric influence and have not been taken into account when calculating the linear relation between acetone and $\mathrm{CO}$ in the stratosphere. The air masses observed in the free troposphere during STREAM98 originated from polar-, midand (sub)tropical latitudes. The chemical age of these air masses has been determined by Fischer et al. (2002) us- ing the $\mathrm{C}_{2} \mathrm{H}_{2} / \mathrm{CO}$ ratio. Air masses originating from polarand mid-latitudes were 5-7 days old. Trajectory analysis shows that air masses originating from (sub)tropical latitudes were transported a few days before reaching the measurement area.

Further stratospheric measurements were performed during STREAM97. Since this campaign focussed on ozone depletion in the lowermost stratosphere, mainly stratospheric measurements are available $\left(\mathrm{O}_{3}>150 \mathrm{ppb}_{\mathrm{v}} ; \mathrm{CO}<60 \mathrm{ppb}_{\mathrm{v}}\right)$. The linear correlation between acetone and $\mathrm{CO}$ had a slope of 3.0 ( $\mathrm{R}^{2}=0.87$; see Fig. 4) (see also Schneider, 1997). A significant correlation between acetone and $\mathrm{CO}$ is not always observed, as is shown for the LBA-CLAIRE campaign. The LBA-CLAIRE measurements were conducted in the boundary layer $(0-1 \mathrm{~km})$ and free troposphere $(1-12.5 \mathrm{~km})$ over the Amazon rain forest and are shown in Figs. 5a and b. The squared correlation coefficient for the linear relation between acetone and $\mathrm{CO}$ was 0.06 in the boundary layer and 0.002 in the free troposphere, and hence, the correlation between acetone and $\mathrm{CO}$ was not significant. 

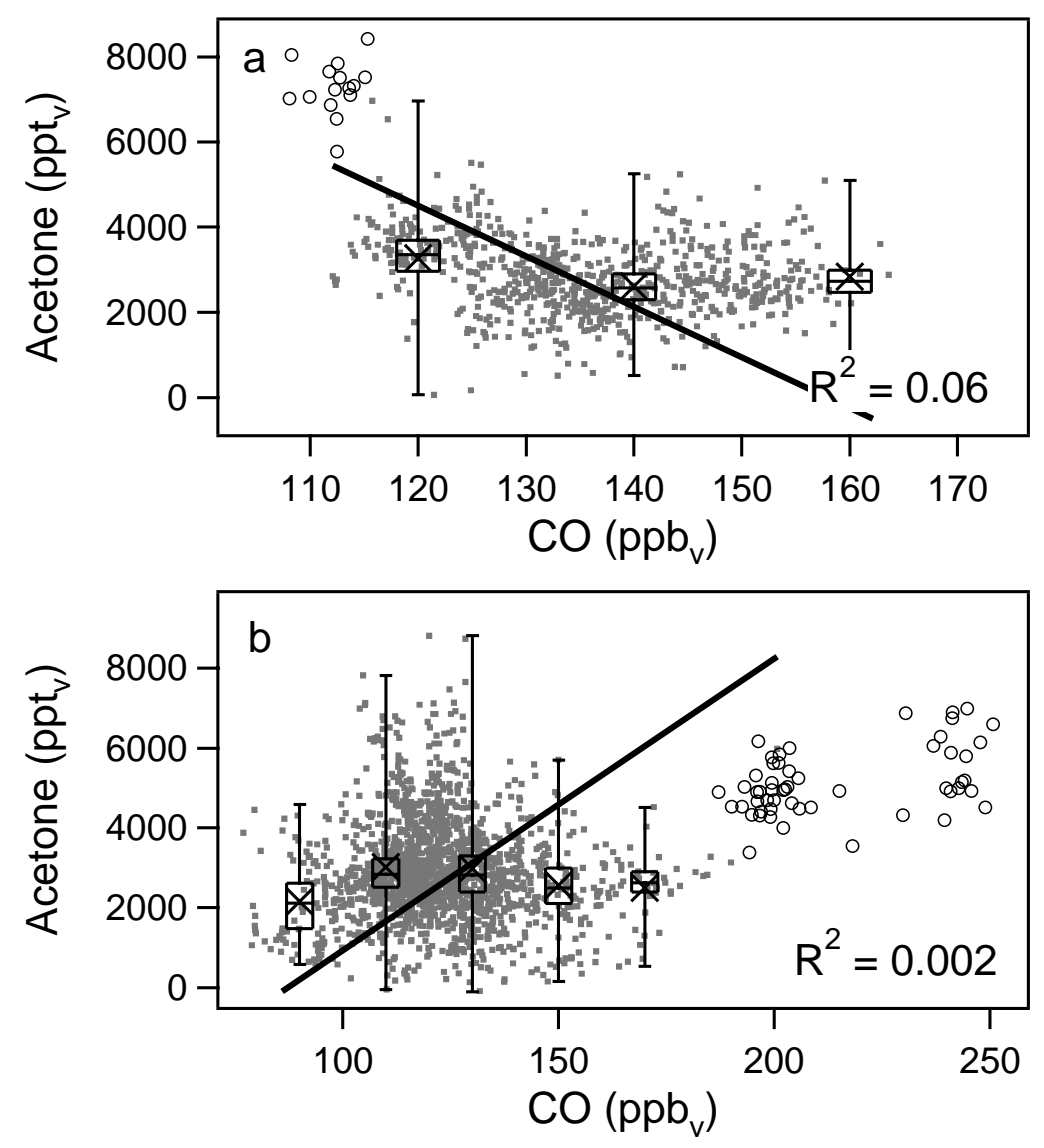

Fig. 5. Acetone and CO mixing ratios observed in (a) the boundary layer $(0-1 \mathrm{~km})$ and (b) free troposphere (1-12.5 km) over the tropical rain forest during LBA-CLAIRE. The open circles represent measurements in the marine boundary layer (a) and in an upper tropospheric biomass burning plume (b).

The boundary layer over Surinam, a largely unpolluted region, is influenced by northeasterly trade winds, which advect air from the Atlantic Ocean over the Amazonian rain forest towards the ITCZ. The air masses over the Surinam rain forest are, hence, not anthropogenically influenced but are mainly subject to biogenic emissions. It is well established that acetone has significant biogenic sources (Crutzen et al., 2000). Large emissions of acetone or acetone precursors (e.g. monoterpenes) can occur from vegetation and/or decaying litter in the tropical rainforests (Warneke et al., 1999; Pöschl et al., 2001). This is evident from the relatively high acetone mixing ratios observed during LBA-CLAIRE. Carbon monoxide has predominantly anthropogenic sources, which explains the lack of correlation between acetone and $\mathrm{CO}$ in areas with strong biogenic emissions. Shallow and deep convective clouds, which were prevalent over the rain forest during the entire measurement period, transported the biogenic emissions to the free troposphere, hence, also the air in the free troposphere was strongly influenced by biogenic emissions and no significant correlation between acetone and $\mathrm{CO}$ was found. Measurements in the marine boundary layer, off the coast of Surinam, and in a biomass burning plume, which was encountered during one flight in the upper free troposphere (Andreae et al., 2001; Williams et al, 2001), were not included in the calculation of the linear relation between acetone and $\mathrm{CO}$. These data points are displayed as open circles in Fig. 5a and b. It can clearly be seen that air masses with a different origin, as the biomass burning plume, show a different correlation. Although the biomass burning plume was encountered during a relatively short time period, yielding only a few data points, a correlation between acetone and $\mathrm{CO}$ can be envisioned. The slope of the linear relation is $18.2 \mathrm{ppt}_{\mathrm{v}}$ acetone/ppb $\mathrm{vO}\left(\mathrm{R}^{2}=0.19\right)$, similar to the slope which has been found in the free troposphere during other experiments. Andreae et al. (2001) calculated an enhancement ratio of $19.5 \pm 1.6 \mathrm{ppt}_{\mathrm{v}}$ acetone/ppb $\mathrm{VO}$ for this biomass burning plume. The high acetone mixing ratios observed in the marine boundary layer might result from the production of acetone by the ocean or long range transport of continental air over the ocean.

A summary of the observed correlations during the above described measurement campaigns is given in Table 2 . 
Table 3. Slope of the linear correlation between acetone and $\mathrm{CO}$ reported in the literature (in $\mathrm{ppt}_{\mathrm{V}} \mathrm{acetone}_{\mathrm{ppb}} \mathrm{CO}$ )

\begin{tabular}{llllll}
\hline Campaign & Place & Time & Slope & Airmass & Reference \\
\hline ABLE3B & Eastern Canada & July/Aug 1990 & 30 & troposphere & Singh et al., 1994 \\
PEM-WEST & Western Pacific & Feb/Mar 1994 & 3 & fresh urban plume & $\begin{array}{l}\text { Singh et al., 1995 } \\
\text { stratosphere }\end{array}$ \\
PEM-WEST & Western Pacific & Feb/Mar 1994 & 6.1 & McKeen et al., 1997 \\
TRACE-A & South Atlantic, & Sept/Oct 1992 & $7.2-10.3$ & biomass burning plumes & Mauzerall et al., 1998 \\
& Africa and Brazil & & & & Andreae et al., 2001 \\
LBA-CLAIRE & Surinam & March 1998 & 19.5 & free troposphere & Reiner et al., 2001 \\
INDOEX & Indian Ocean & 11 March 1999 & 14 & boundary layer & Reiner et al., 2001 \\
INDOEX & Indian Ocean & 24 Feb 1999 & 3.4 & free troposphere & Wisthaler et al., 2002 \\
INDOEX & Indian Ocean & March 1999 & 17.2 & boundary layer & Wisthaler et al., 2002 \\
INDOEX & Indian Ocean & March 1999 & 13.4 & boundary layer & Jost et al., 2003 \\
SAFARI & Namibia & Sept 2000 & $4.8-11.3$ & fresh biomass burning plume & Jas \\
\hline
\end{tabular}

\footnotetext{
${ }^{1}$ Measurements between 0 and $6 \mathrm{~km}$ altitude.

${ }^{2}$ Aged biomass burning plume.

${ }^{3}$ These measurements were partly performed in the southern hemisphere.

${ }^{4}$ Air masses originating from the west coast of India.

${ }^{5}$ Air masses originating from the Bay of Bengal.
}

\section{Comparison with literature values}

A positive correlation between acetone and $\mathrm{CO}$ has been described by several authors. Singh et al. (1994) were the first to show a strong correlation between acetone and $\mathrm{CO}$ mixing ratios in the atmosphere. They derived a linear relation between acetone and $\mathrm{CO}$ with a slope of $30 \mathrm{ppt}_{\mathrm{v}}$ acetone/ppb $\mathrm{CO}$ during the Arctic Boundary Layer Experiment (ABLE3B) between 0 and $6 \mathrm{~km}$ altitude. The authors also noted the striking difference between the enhancement ratio in industrial plumes and in aged air masses, due to the secondary production of acetone from hydrocarbons.

The slope, which has been used frequently to initialise acetone mixing ratios in model calculations, is $6.1 \mathrm{ppt}_{\mathrm{v}}$ acetone/ppb $\mathrm{v}_{\mathrm{v}}$ CO (e.g. McKeen et al., 1997; Keim et al., 1999; Frost et al., 2002), and has been observed in the stratosphere during PEM-WEST B. This slope is based on data published by Singh et al. (1997), however, the linear relation is described by McKeen et al. (1997). During the same experiment an enhancement ratio of $3 \mathrm{ppt}_{\mathrm{v}}$ acetone/ppb $\mathrm{CO}$ was found in a plume of relatively fresh Asian emissions over the western Pacific (Singh et al., 1995).

Some values for the slope of the linear relation between acetone and $\mathrm{CO}$ are published for the INDOEX campaign. Reiner et al., (2001) observed a slope of $14 \mathrm{ppt}_{\mathrm{v}}$ acetone/ppb $\mathrm{CO}$ for a measurement flight of the NCAR-C130 aircraft in the marine boundary layer during INDOEX. Another flight in the free troposphere, which was for a large part conducted in the southern hemisphere, indicated a slope of $3.4 \mathrm{ppt}_{\mathrm{v}}$ acetone/ppb $\mathrm{v}_{\mathrm{v}} \mathrm{CO}$. In a third case study they analysed the acetone-CO relation for the residual boundary layer, a polluted layer between 2 and $4 \mathrm{~km}$ altitude, containing rela- tively fresh biomass and fossil fuel burning emissions. In this layer, the slope ranged between 8.8 and $11 \mathrm{ppt}_{\mathrm{v}}$ acetone/ppb $\mathrm{CO}$, which is comparable to the acetone- $\mathrm{CO}$ enhancement ratio observed in biomass burning plumes during TRACE-A (Mauzerall et al., 1998).

A large range of enhancement factors have been observed in biomass burning plumes, depending on the age of the plume. In laboratory experiments very young plumes can be investigated, and hence, direct emissions from biomass burning can be determined. Holzinger et al. (1999) found an enhancement factor of $5.4 \mathrm{ppt}_{\mathrm{v}}$ acetone/ppb $\mathrm{v} \mathrm{CO}$ from a laboratory biomass burning experiment. Jost et al. (2003) performed in-situ measurements over a very young biomass burning plume in Namibia, with a plume age up to about 2 hours. They found the acetone enhancement ratio to increase with air mass age from $4.8 \mathrm{ppt}_{\mathrm{v}}$ acetone/ $\mathrm{ppb}_{\mathrm{v}} \mathrm{CO}$ directly over the fire to $11.3 \mathrm{ppt}_{\mathrm{v}}$ acetone/ $\mathrm{ppb}_{\mathrm{v}} \mathrm{CO}$ in a biomass burning plume with an age of about 2 hours, indicating the importance of secondary production of acetone in the biomass burning plume. More aged biomass burning plumes, which were analysed in the boundary layer and free troposphere over the tropical south Atlantic Ocean showed an enhancement ratio of 7.2-10.3 ppt $_{\mathrm{v}}$ acetone/ppb $\mathrm{v}$ CO for plumes which were between 0.5 and about 6 days old, whereas no significant enhancement was observed in a very young plume (Mauzerall et al., 1998). An even older biomass burning plume was investigated by Andreae et al. (2001) in the upper free troposphere over the Amazonian rainforest. They calculated the acetone enhancement factor to be $19.5 \pm 1.6 \mathrm{ppt}_{\mathrm{v}}$ acetone/ppb $\mathrm{v} \mathrm{CO}$ and the plume age 9-10 days.

Wisthaler et al. (2002) presented shipborne measurements in the marine boundary layer over the northern Indian Ocean 


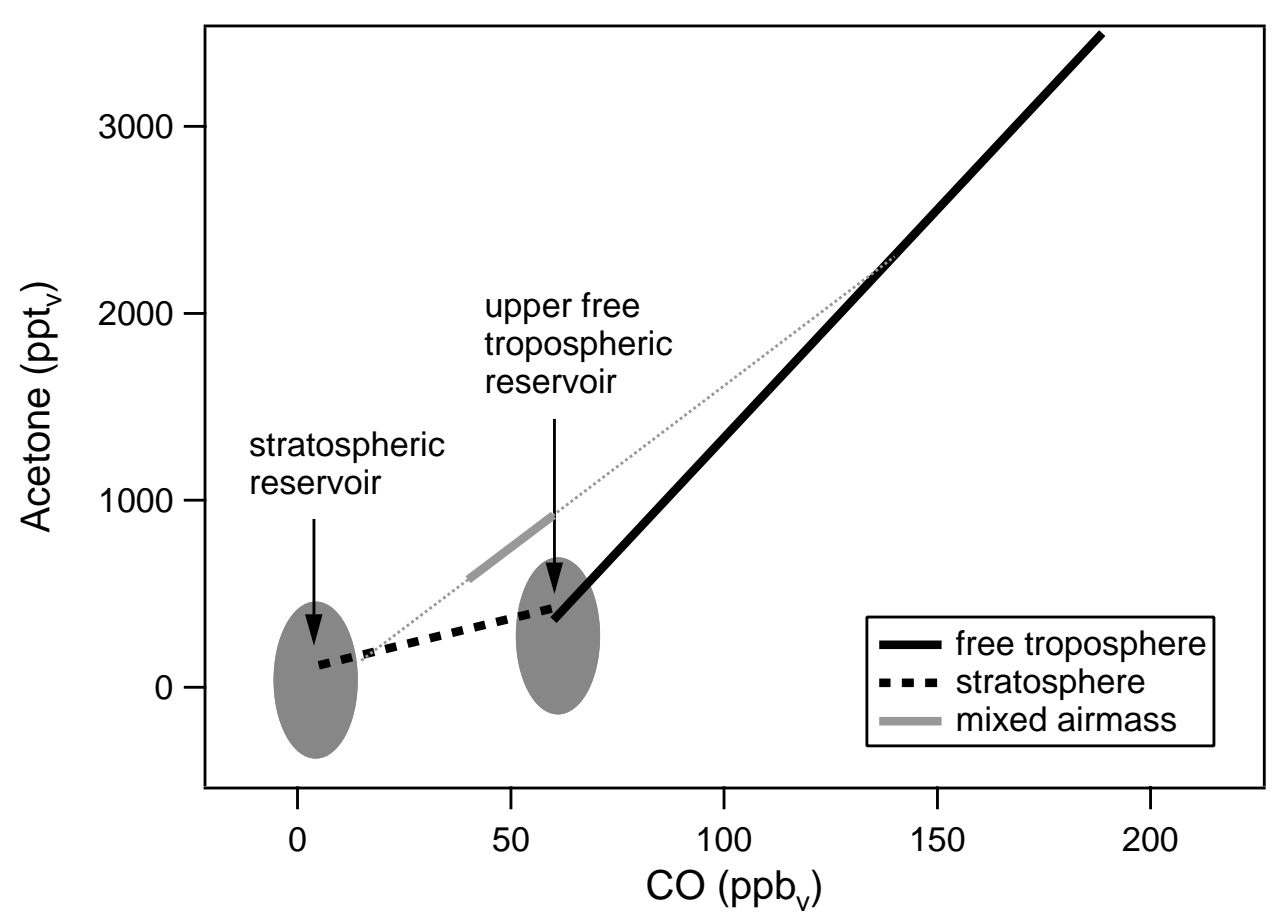

Fig. 6. Acetone-CO correlations observed during STREAM98. The grey solid line represents the acetone-CO correlation which was found in stratospheric air masses with a strong tropospheric influence (mixed air masses). The grey dashed line shows the mixing line corresponding to these air masses.

during INDOEX. They subdivided the data into air masses originating from the west-coast of India and from the Bay of Bengal and found a slope of 17.2 and $13.4 \mathrm{ppt}_{\mathrm{v}}$ acetone/ $\mathrm{ppb}_{\mathrm{v}}$ $\mathrm{CO}$, respectively. Table 3 gives a summary of the slope of the acetone- $\mathrm{CO}$ correlation found in the literature.

\section{Discussion}

A striking result of this study is the comparable slope of the linear acetone-CO relation in the anthropogenically influenced free troposphere and marine boundary layer, in very different regions of the world and at very different time periods of the year.

First of all we have to address the question why a correlation between acetone and $\mathrm{CO}$ is observed at all. The most simple explanation is that in anthropogenically polluted areas, although $\mathrm{CO}$ and acetone might have different physical sources, the emission distribution is very similar, leading to a good correlation between acetone and $\mathrm{CO}$ mixing ratios. This has also been observed in fresh urban emission plumes (Singh et al., 1995). Fresh anthropogenic and biomass burning emissions, however, show a much smaller slope than aged plumes, indicating the importance of secondary acetone production from higher hydrocarbons, which is discussed in detail below. In order to maintain a good correlation, these hydrocarbons should have similar source patterns as CO.
Moreover, mixing of air masses, originating from very different "reservoirs", can also cause a linear relation between two trace gases. To illustrate this, the linear correlations which we observed during the STREAM98 campaign are plotted in Fig. 6. The observed correlation between acetone and $\mathrm{CO}$ in the stratosphere can be explained by mixing an air mass from the stratospheric reservoir, containing low acetone and $\mathrm{CO}$ mixing ratios, with an air mass from the upper free tropospheric reservoir, which contains higher acetone and $\mathrm{CO}$ mixing ratios. Moreover, the acetone-CO correlation in the mixed air masses, which have been described in Sect. 3 and are shown as open circles in Fig. 3b, can be explained by mixing of a stratospheric air mass with a free tropospheric air mass originating from much lower altitude. However, for the troposphere no clear reservoirs exist which could explain the observed slopes in the marine boundary layer and the free troposphere (see Fig. 8).

Due to the difference in lifetime of acetone and CO, especially in the free troposphere, the slope of the linear relation should decrease with air mass age. To illustrate this we calculated the change in the slope of the linear acetone-CO relation observed in the free troposphere during STREAM98, considering a $\mathrm{CO}$ and acetone lifetime of 38 and 14 days, respectively. These lifetimes have been calculated based on the depletion of $\mathrm{CO}$ and acetone through their reaction with $\mathrm{OH}$, assuming an $\mathrm{OH}$ concentration of $1.7 \cdot 10^{6}$ molecules $/ \mathrm{cm}^{3}$, and the destruction of acetone through photolysis. The $\mathrm{OH}$ 


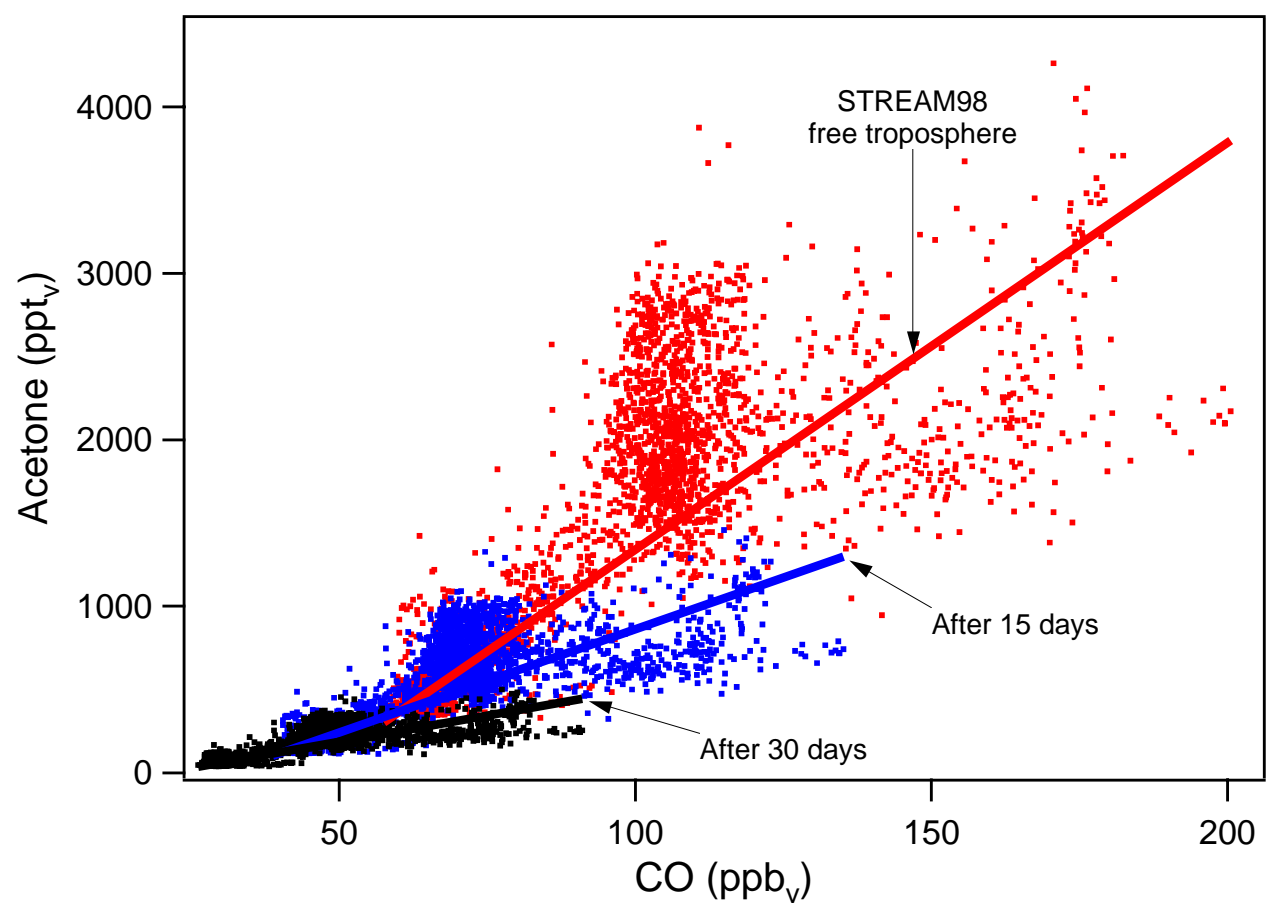

Fig. 7. Acetone-CO correlation observed in the free troposphere during STREAM98 (red line and markers). Acetone-CO correlation after 15 (blue) and 30 days (black), assuming a lifetime of $\mathrm{CO}$ and acetone of 38 and 14 days, respectively.

reaction rates have been adopted from DeMore et al. (1997) and Wollenhaupt et al. (2000), the photolysis rates from Brühl and Crutzen (1989). An exponential decay has been assumed using the lifetime as e-folding time. The results are shown in Fig. 7. The observed slope of the acetone$\mathrm{CO}$ relation in the free troposphere during STREAM98 was $24.4 \mathrm{ppt}_{\mathrm{v}}$ acetone/ppb $\mathrm{v}$ CO. After 15 days this slope has decreased to $11.7 \mathrm{ppt}_{\mathrm{v}}$ acetone/ppb $\mathrm{pb}_{\mathrm{v}}$ and after 30 days to $6.3 \mathrm{ppt}_{\mathrm{v}}$ acetone/ppb $\mathrm{v} \mathrm{CO}$, which is close to the observed slope in the stratosphere. Note that only depletion of both gases is considered and no production or additional emission has been taken into account.

The air mass age of the free tropospheric air masses observed during INDOEX, STREAM98 and MINOS ranged between 4 and 15 days. According to the calculations above, there should be an additional source of acetone in the free troposphere to prevent the slope of the linear acetone-CO relation from decreasing with air mass age. This additional acetone source should be stronger in the tropics compared to mid-latitudes, since the acetone photolysis rates are higher in the tropics (Singh et al., 2000), suggesting that this acetone source might be dependent on radiation as well. The secondary production of acetone from different hydrocarbons, which are co-emitted with acetone and CO (Singh et al., 1994), and the direct release of acetone from organic aerosols (Ellison et al., 1999) have been suggested. The C3C5 isoalkanes (propane, isobutene, isopentane) are considered the major anthropogenic atmospheric precursors of acetone (Jacob et al., 2002).
A summary of all linear acetone-CO relations obtained in this study is presented in Fig. 8. When comparing the acetone-CO relations derived in the marine boundary layer and the free troposphere during INDOEX it can be seen that at low CO mixing ratios acetone in the marine boundary layer is enhanced compared to the free troposphere, while at high $\mathrm{CO}$ mixing ratios acetone mixing ratios are lower in the marine boundary layer. This might be an indication for the release of acetone from the ocean in relatively clean regions and the uptake of acetone by the ocean in more polluted areas. This rather speculative conclusion is supported by model simulations with the ECHAM global chemistryclimate model performed by de Laat et al. (2001). They had to include an oceanic source of acetone in order to simulate the observed acetone mixing ratios in the marine boundary layer during INDOEX at low CO mixing ratios. At the same time they overestimate the acetone mixing ratios at $\mathrm{CO}$ mixing ratios exceeding $100 \mathrm{ppb}_{\mathrm{v}}$, indicating a missing acetone sink. A similar pattern has been observed over the Mediterranean Sea during MINOS, hence, this effect is not limited to the Indian Ocean.

The observations in the lower stratosphere indicate a tendency in the slope of the acetone-CO correlation with distance above the tropopause. During STREAM97, measurements were performed at high latitudes during wintertime, when the tropopause was situated below $10 \mathrm{~km}$ altitude, and ozone mixing ratios up to $700 \mathrm{ppb}_{\mathrm{v}}$ were observed. The STREAM98 measurements were performed at mid-latitudes during summertime, when the tropopause was located at 


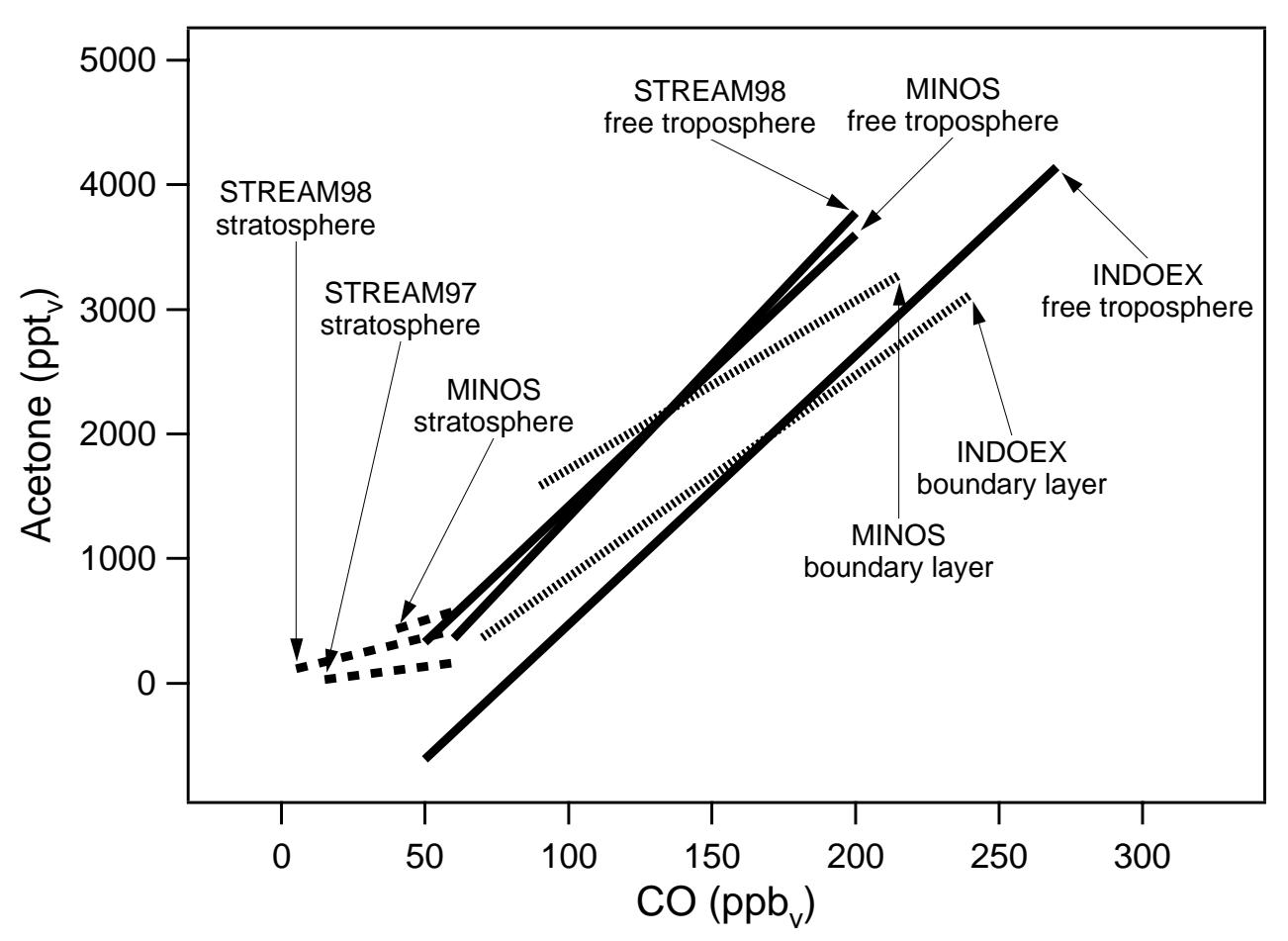

Fig. 8. All linear acetone-CO correlations derived in this study.

much higher altitudes $(10-14 \mathrm{~km})$ and the maximum observed $\mathrm{O}_{3}$ mixing ratio was $500 \mathrm{ppb}_{\mathrm{v}}$. Over the Mediterranean region in summer, the tropopause is generally located at $15-16 \mathrm{~km}$, well above the maximum cruising altitude of the aircraft. During MINOS stratospheric measurements were performed during one flight, when the tropopause was depressed to about $10 \mathrm{~km}$ in a tropopause fold, and $\mathrm{O}_{3}$ mixing ratios up to $280 \mathrm{ppb}_{\mathrm{v}}$ were observed.

Based on the observed $\mathrm{O}_{3}$ mixing ratios and tropopause heights, the measurements during STREAM97 were performed deepest into the stratosphere and showed the smallest slope of the linear relation between acetone and $\mathrm{CO}\left(3.1 \mathrm{ppt}_{\mathrm{v}}\right.$ acetone/ppb $\mathrm{v}$ CO). The stratospheric MINOS measurements were performed closest to the tropopause and show the highest slope (7.1 $\mathrm{ppt}_{\mathrm{v}}$ acetone/ppb $\mathrm{v}$ CO). Hence, the slope of the acetone- $\mathrm{CO}$ relation decreases with distance from the tropopause, probably due to the longer lifetime of $\mathrm{CO}$ compared to acetone in the lower stratosphere and the decreasing influence of free tropospheric air (mixing) with increasing distance from the tropopause. The longer lifetime of $\mathrm{CO}$ compared to acetone in the lower stratosphere is a result of the increasing photolytic destruction of acetone with altitude and the decreasing chemical destruction of $\mathrm{CO}$ by its reaction with $\mathrm{OH}$, due to the decreasing $\mathrm{OH}$ mixing ratio with altitude. Moreover, $\mathrm{CO}$ is continuously produced from methane, whereas acetone has no significant sources in the lower stratosphere.
The intercepts of the linear relations between acetone and $\mathrm{CO}$ are displayed in Table 2. If we assume that biogenic emissions only significantly enhance the acetone mixing ratio in the atmosphere and not the $\mathrm{CO}$ mixing ratio, the different intercepts might be an indication for the background acetone mixing ratio caused by biogenic emissions. In the free troposphere, the intercept increases from INDOEX to STREAM98 and MINOS, which can be explained by the fact that eastern Europe and Canada are much more heavily vegetated areas compared to the Indian subcontinent. Assuming a background $\mathrm{CO}$ mixing ratio, due to methane chemistry, in the free troposphere of $60 \mathrm{ppb}_{\mathrm{v}}$, the background acetone mixing ratio would be $546 \mathrm{ppt}_{\mathrm{v}}, 359 \mathrm{ppt}_{\mathrm{v}}$ and $-396 \mathrm{ppt}_{\mathrm{v}}$ for MINOS, STREAM98 and INDOEX, respectively. For MINOS and STREAM98 this is comparable to the background acetone mixing ratio of $500 \mathrm{ppt}_{\mathrm{v}}$, observed in the northern hemisphere by Singh et al. (1995). In the marine boundary layer a background acetone mixing ratio of 1179 and 202 ppt $_{\mathrm{v}}$ can be found at a CO mixing ratio of $60 \mathrm{ppb}_{\mathrm{v}}$ for MINOS and INDOEX, respectively. The relatively high background acetone mixing ratio in the marine boundary layer over the Mediterranean could be an indication for recent biogenic emissions during MINOS, which has also been suggested by Salisbury et al. (2003). This discussion shows the importance of estimating an acetone background mixing ratio, when using the acetone- $\mathrm{CO}$ correlation to initialise acetone mixing ratios in model calculations. 
We have to note that most of our measurements took place downwind of large continents during summertime. Extensive measurements in the continental boundary layer, in the southern hemisphere and measurements during other seasons will be necessary to complete the picture of the relation between acetone and $\mathrm{CO}$ in the atmosphere.

\section{Summary and conclusions}

The correlation between acetone and $\mathrm{CO}$ has been investigated for five aircraft measurement campaigns, at midlatitudes, polar and tropical regions, showing common slopes for different layers of the atmosphere. Acetone measurements were performed using a proton-transfer-reaction or chemical ionisation mass spectrometer with a total uncertainty ranging from 28 to $50 \%$. CO was measured using a tunable diode laser absorption spectrometer (TDLAS) with a total uncertainty ranging between 1.4 and $14 \%$.

Air masses which were influenced by anthropogenic pollution and biomass burning show a strong correlation between acetone and $\mathrm{CO}$. This is caused by the co-emission of acetone, $\mathrm{CO}$ and hydrocarbons by anthropogenic and biomass burning sources, and the secondary production of acetone from the oxidation of various hydrocarbons. In the marine boundary layer, the slope of the linear relation between acetone and $\mathrm{CO}$ ranged between 13 and $16 \mathrm{ppt}_{\mathrm{v}}$ acetone/ppb $\mathrm{v}_{\mathrm{v}} \mathrm{CO}$, while it was between 21 and $25 \mathrm{ppt}_{\mathrm{v}}$ acetone/ $/ \mathrm{ppb}_{\mathrm{v}} \mathrm{CO}$ in the free troposphere. The difference in slope can be explained by the emission of acetone from the ocean in relatively clean air masses and the uptake of acetone by the ocean in polluted areas.

Close to biogenic sources no correlation between acetone and $\mathrm{CO}$ was observed, which is due to the strong biogenic emission of acetone and its precursor gases, and small coincident biogenic $\mathrm{CO}$ emissions.

At further distance from biogenic and anthropogenic sources, for example in the stratosphere or in the southern hemisphere, a strong correlation between acetone and CO was observed as well. Measurements in the lower stratosphere indicate a slope between 3 and $7 \mathrm{ppt}_{\mathrm{v}}$ acetone/ppb $\mathrm{CO}$. Measurements over the Indian Ocean in the southern hemisphere $3.4 \mathrm{ppt}_{\mathrm{v}}$ acetone/ppb $\mathrm{v} \mathrm{CO}$. This is probably caused by the relatively longer lifetime of $\mathrm{CO}$ compared to acetone, which causes the slope of the acetone- $\mathrm{CO}$ correlation to decrease with air mass age.

The slopes of the linear relation between acetone and CO, presented in this study, may be used in model calculations. However, different slopes have to be considered for marine boundary layer, free tropospheric and lower stratospheric air masses, and a distinction has to be made between northern and southern hemispheric air. The acetone-CO correlation can, however, not be used in areas with high biogenic emissions, since no significant correlation between acetone and $\mathrm{CO}$ was observed in these areas. Moreover, an acetone back- ground mixing ratio has to be assumed in order to use the acetone-CO correlation in model calculations.

The acetone- $\mathrm{CO}$ correlation may also be useful for the identification of source regions that have affected the air mass.

Acknowledgements. The STREAM project was financially supported by the European Union (DG XII). Support by the Max Planck Society is also gratefully acknowledged (MINOS, INDOEX and LBA-CLAIRE).

\section{References}

Andreae, M. O., Artaxo, P., Fischer, H., Freitas, S. R., Gregoire, J. M., Hansel, A., Hoor, P., Kormann, R., Krejci, R., Lange, L., Lelieveld, J., Lindinger, W., Longo, K., Peters, W., de Reus, M., Scheeren, B., Silva Dias, M. A. F., Ström, J., van Velthoven, P. F. J., and Williams, J.: Transport of biomass burning smoke to the upper troposphere by deep convection in the equatorial region, Geophys. Res. Lett., 28, 951-954, 2001.

Arnold, F., Bürger, V., Droste-Fanke, B., Grimm, F., Krieger, A., Schneider, J., and Stilp, T.: Acetone in the upper troposphere and lower stratosphere: Impact on trace gases and aerosols, Geophys. Res. Lett., 24, 3017-3020, 1997.

Brühl, C. and Crutzen, P. J.: On the disproportionate role of tropospheric ozone as a filter against solar UV-B radiation, Geophys. Res. Lett., 16, 703-706, 1989.

Crutzen, P. J., Williams, J., Pöschl, U., Hoor, P., Fischer, H., Warneke, C., Holzinger, R., Hansel, A., Lindinger, W., Scheeren, B., and Lelieveld, J.: High spatial and temporal resolution measurements of primary organics and their oxidation products over the tropical forests of Surinam, Atm. Env., 34, 1161-1165, 2000.

de Gouw, J. A., Warneke, C., Scheeren, H. A., van der Veen, C., Bolder, M., Scheele, M. P., Williams, J., Wong, S., Lange, L., Fischer, H., and Lelieveld, J.: Overview of the trace gas measurements onboard the Citation aircraft during the intensive field phase of INDOEX, J. Geophys. Res., 106, 28 453-28 467, 2001.

de Laat, A. T. J., de Gouw, J. A., Lelieveld, J., and Hansel, A.: Model analysis of trace gas measurements and pollution impact during INDOEX, J. Geophys. Res., 106, 28 469-28 480, 2001.

De More, W. B., Sander, S. P., Golden, D. M., Hampson, R. F., Kurylo, M. J., Howard, C. J., Ravishankara, A. R., Kolb, C. E., and Molina, M. J.: Chemical kinetics and photochemical data for use in stratospheric modeling, Evaluation Number 12, Jet Propulsion Laboratory publication no. 97-4, Pasadena, CA, 1997.

de Reus, M., Krejci, R., Williams, J., Fischer, H., Scheele, R., and Ström, J.: Vertical and horizontal distribution of the aerosol number concentration and size distribution over the northern Indian Ocean, J. Geophys. Res., 106, 28 629-28 641, 2001.

Ellison, G. B., Tuck, A. F., and Vaida, V.: Atmospheric processing of organic aerosols, J. Geophys. Res., 104, 11 633-11 641, 1999.

Fischer, H., Wienhold, F. G., Hoor, P., Bujok, O., Schiller, C., Siegmund, P., Ambaum, M., Scheeren, H. A., and Lelieveld, J.: Tracer correlations in the northern high latitude lowermost stratosphere: Influence of cross-tropopause mass exchange, Geophys. Res. Lett., 27, 97-100, 2000.

Fischer, H., Brunner, D., Harris, G. W., Hoor, P., Lelieveld, J., McKenna, D. S., Rudolph, J., Scheeren, H. A., Siegmund, P., Wernli, H., Williams, J., and Wong, S.: Synoptic tracer 
gradients in the upper troposphere over central Canada during the Stratosphere-Troposphere Experiments by Aircraft Measurements 1998 summer campaign, J. Geophys. Res., 107(D8), 4064, doi: 10.1029/2000JD000312, 2002.

Frost, G. J., Fried, A., Lee, Y.-N., Wert, B., Henry, B., Drummond, J. R., Evans, M. J., Fehsenfeld, F. C., Goldan, P. D., Holloway, J. S., Hübler, G., Jakoubek, R., Jobson, B. T., Knapp, K., Kuster, W. C., Roberts, J., Rudolph, J., Ryerson, T. B., Stohl, A., Stroud, C., Sueper, D. T., Trainer, M., and Williams, J.: Comparison of box model calculations and measurements of formaldehyde from the 1997 North Atlantic Regional Experiment, J. Geophys. Res., 107(D8), 4060, doi:10.1029/2001JD000896, 2002.

Holzinger, R., Warneke, C., Hansel, A., Jordan, A., and Lindinger, W.: Biomass burning as a source of formaldehyde, acetaldehyde, methanol, acetone, acetonitrile and hydrogen cyanide, Geophys. Res. Lett., 26, 1161-1164, 1999.

Hoor, P., Fischer, H., Lange, L., Lelieveld, J., and Brunner, D.: Seasonal variations of a mixing layer in the lowermost stratosphere as identified by the $\mathrm{CO}-\mathrm{O}_{3}$ correlation from in situ measurements, J. Geophys. Res., 107(D5), 4044, doi:10.1029/2000JD000289, 2002.

Jacob, D. J., Field, B. D., Jin, E. M., Bey, I., Li, Q., Logan, J. A., Yantosca, R., and Singh, H. B.: Atmospheric budget of acetone, J. Geophys. Res., 107(D10), 4100, doi:10.1029/2001JD000694, 2002.

Jost, C., Trentmann, J., Sprung, D., Andreae, M. O., McQuaid, J. B., and Barjat, H.: Trace gas chemistry in a young biomass burning plume over Namibia: Observations and model simulations, J. Geophys. Res.,108(D13), 8482, doi:10.1029/2002JD002431, 2003.

Keim, E. R., McKeen, S. A., Gao, R. S., Donnelly, S. G., Wamsley, R. C., Del Negro, L. A., Fahey, D. W., Hanisco, T. F., Lanzendorf, E. J., Proffitt, M. H., Margitan, J. J., Hintsa, E. J., Jaegle, L., Webster, C. R., May, R. D., Scott, D. C., Salawitch, R. J., Wilson, J. C., McElroy, C. T., Atlas, E. L., Flocke, F., and Bui, T. $\mathrm{P}$.: $\mathrm{NO}_{\mathrm{y}}$ partitioning from measurements of nitrogen and hydrogen radicals in the upper troposphere, Geophys. Res. Lett., 26, 51-54, 1999.

Kormann, R., Fischer, H., Gurk, C., Helleis, F., Klüpfel, T., Kowalski, K., Königstedt, R., Parchatka, U., and Wagner, V.: Application of a multi-laser tunable diode laser absorption spectrometer for atmospheric trace gas measurements at sub-ppb $b_{\mathrm{V}}$ levels, Spectrochim. Acta A, 58, 2489-2498, 2002.

Lelieveld, J., Crutzen, P. J., Ramanathan, V., Andreae, M. O., Brenninkmeijer, C. A. M., Campos, T., Cass, G. R., Dickerson, R. R., Fischer, H., de Gouw, J. A., Hansel, A., Jefferson, A., Kley, D., de Laat, A. T. J., Lal, S., Lawrence, M. G., Lobert, J. M., Mayol-Bracero, O., Mitra, A. P., Novakov, T., Oltmans, S. J., Prather, K. A., Ramanathan, V., Reiner, T., Rodhe, H., Scheeren, H. A., Sikka, D., and Williams, J.: The Indian Ocean Experiment: Widespread air pollution from South and Southeast Asia, Science, 291, 1031-1036, 2001.

Lelieveld, J., Berresheim, H., Borrmann, S., Crutzen, P. J., Dentener, F. J., Fischer, H., Feichter, J., Flatau, P. J., Heland, J., Holzinger, R., Kormann, R., Lawrence, M. G., Levin, Z., Markowicz, K., Mihalopoulos, N., Minikin, A., Ramanthan, V., de Reus, M., Roelofs, G. J., Scheeren, H. A., Sciare, J., Schlager, H., Schulz, M., Siegmund, P., Steil, B., Stephanou, E. G., Stier, P., Traub, M., Warneke, C., Williams, J., and Ziereis, H.: Global air pollution crossroads over the Mediterranean, Science, 298, 794-799, 2002.

Lindinger, W., Hansel, A., and Jordan, A.: On-line monitoring of volatile organic compounds at $\mathrm{ppt}_{\mathrm{V}}$ levels by means of ProtonTransfer-Reaction Mass Spectrometry (PTR-MS): Medical applications, food control and environmental research, Int. J. Mass Spectrom. Ion Processes, 173, 191-241, 1998.

Mauzerall, D. L., Logan, J. A., Jacob, D. J., Anderson, B. E., Blake, D. R., Bradshaw, J. D., Heikes, B., Sachse, G. W., Singh, H., and Talbot, B.: Photochemistry in biomass burning plumes and implications for tropospheric ozone over the tropical South Atlantic, J. Geophys. Res., 103, 8401-8423, 1998.

McKeen, S. A., Gierczak, T., Burkholder, J. B., Wennberg, P. O., Hanisco, T. F., Keim, E. R., Gao, R. S., Liu, S. C., Ravishankara, A. R., and Fahey, D. W.: The photochemistry of acetone in the upper troposphere: A source of odd-hydrogen radicals, Geophys. Res. Lett., 24, 3177-3180, 1997.

Möhler, O., Reiner, T., and Arnold, F.: A novel aircraft-based tandem mass spectrometer for atmospheric ion and trace gas measurement, Rev. Sci. Instrum., 64, 1199-1207, 1993.

Pöschl, U., Williams, J., Hoor, P., Fischer, H., Crutzen, P. J., Warneke, C., Holzinger, R., Hansel, A., Jordan, A., Lindinger, W., Scheeren, H. A., Peters, W., and Lelieveld, J.: High acetone concentrations throughout the $0-12 \mathrm{~km}$ altitude range over the tropical rainforest in Surinam, J. Atm. Chem., 38, 115-132, 2001.

Press, W. H., Teukolsky, S. A., Vetterling, W. T., and Flannery, B. P.: Numerical Recipes in C: the Art of Scientific Computing, 2nd edition, Cambridge University Press, New York, pp. 994, 1992.

Reiner, T., Sprung, D., Jost, C., Gabriel, R., Mayol-Bracero, O. L., Andreae, M. O., Campos, T. L., and Shetter, R. E.: Chemical characterization of pollution layers over the tropical Indian Ocean: Signatures of emissions from biomass and fossil fuel burning, J. Geophys. Res., 106, 28 97-28 510, 2001.

Salisbury, G., Williams, J., Holzinger, R., Gros, V., Mihalopoulos, N., Vrekoussis, M., Sarda-Estève, R., Berresheim, H., von Kuhlmann, R., Lawrence, M., and Lelieveld, J.: Ground-based PTR-MS measurements of reactive organic compounds during the MINOS campaign in Crete, July-August 2001, Atmos. Chem. Phys., 3, 925-940, 2003.

Scheeren, H. A., Lelieveld, J., Roelofs, G. J., Williams, J., Fischer, H., de Reus, M., de Gouw, J. A., Warneke, C., Holzinger, R., Schlager, H., Klüpfel, T., Bolder, M., van der Veen, C., and Lawrence, M.: The impact of monsoon outflow from India and South-East Asia in the upper troposphere over the eastern Mediterranean, Atmos. Chem. Phys. Discuss., 3, 2285-2330, 2003.

Schneider, J.: Aircraft-based mass spectrometric measurements of trace gas distributions in the tropopause region: Implications for stratosphere-troposphere exange, ozone chemistry and global biomass burning, PhD. thesis, Heidelberg University, Germany, 132 p., 1997.

Singh, H. B., O'Hara, D., Herlth, D., Sachse, W., Blake, D. R., Bradshaw, J. D., Kanakidou, M., and Crutzen, P. J.: Acetone in the atmosphere: distribution, sources, and sinks, J. Geophys. Res., 99, 1805-1819, 1994.

Singh, H. B, Kanakidou, M., Crutzen, P. J., and Jacob, D. J.: High concentrations and photochemical fate of oxygenated hydrocarbons in the global troposphere, Nature, 378, 50-54, 1995. 
Singh, H. B., Chen, Y., Gregory, G. L., Sachse, G. W., Talbot, R., Blake, D. R., Kondo, Y., Bradshaw, J. D., Heikes, B., and Thornton, D.: Trace chemical measurements from the northern midlatitude lowermost stratosphere in early spring: Distributions, correlations and fate, Geophys. Res. Lett., 24, 127-130, 1997.

Singh, H., Chen, Y., Tabazadeh, A., Fukui, Y., Bey, I., Yantosca, R., Jacob, D., Arnold, F., Wohlfrom, K., Atlas, E., Flocke, F., Blake, D., Blake, N., Heikes, B., Snow, J., Talbot, R., Gregory, G., Sachse, G., Vay, S., and Kondo, Y.: Distribution and fate of selected oxygenated organic species in the troposphere and lower stratosphere over the Atlantic, J. Geophys. Res., 105, 3795-3805, 2000.

Sprung, D., Jost, C., Reiner, T., Hansel, A., and Wisthaler, A.: Acetone and acetonitrile in the tropical Indian Ocean boundary layer and free troposphere: aircraft-based intercomparison of AP-CIMS and PTR-MS measurements, J. Geophys. Res., 106, 28 511-28 527, 2001.

Traub, M., Fischer, H., de Reus, M., Kormann, R., Heland, J., Ziereis, H., Schlager, H., Holzinger, R., Williams, J., Warneke, C., de Gouw, J., and Lelieveld, J.: Chemical characteristics assigned to trajectory clusters during the MINOS campaign, Atmos. Chem. Phys., 3, 459-468, 2003.

Warneke, C., Karl, T., Judmaier, H., Hansel, A., Jordan, A., Lindinger, W., and Crutzen, P. J.: Acetone, methanol, and other partially oxidized volatile organic emissions from dead plant matter by abiological processes: Significance for atmospheric $\mathrm{HO}_{\mathrm{x}}$ chemistry, Global Biogeochem. Cycles, 13, 9-17, 1999.
Warneke, C. and de Gouw, J. A.: Organic trace gas composition of the marine boundary layer over the northwest Indian Ocean in April 2000, Atm. Env., 35, 5923-5933, 2001.

Warneke, C., van der Veen, C., Luxembourg, S., de Gouw, J. A., and Kok, A.: Measurements of benzene and toluene in ambient air using proton-transfer-reaction mass spectrometry: calibration, humidity dependence, and field intercomparison, Int. J. Mass Spectrom., 207, 167-182, 2001.

Wienhold, F. G, Fischer, H., Hoor, P., Wagner, V., Königstedt, R., Harris, G. W., Anders, J., Grisar, R., Knothe, M., Riedel, W. J., Lübken, F. J., and Schilling, T.: TRISTAR - a tracer in situ TDLAS for atmospheric research, Appl. Phys. B., 67, 411-417, 1998.

Williams, J., Fischer, H., Hoor, P., Pöschl, U., Crutzen, P. J., Andreae, M. O., and Lelieveld, J.: The influence of the tropical rainforest on atmospheric $\mathrm{CO}$ and $\mathrm{CO}_{2}$ as measured by aircraft over Surinam, South America, Chemosphere - Global Change Science, 3, 157-170, 2001.

Wisthaler, A., Hansel, A., Dickerson, R. R., and Crutzen, P. J.: Organic trace gas measurements by PTR-MS during INDOEX 1999, J. Geophys. Res., 107(D19), 8024, doi:10.1029/2001JD000576, 2002.

Wohlfrom, K. H., Hauler, T., Arnold, F., and Singh, H.: Acetone in the free troposphere and lower stratosphere: Aircraft-based CIMS and GC measurements over the North Atlantic and a first comparison, Geophys. Res. Lett., 26, 2849-2852, 1999.

Wollenhaupt, M., Carl, S. A., Horowitz, A., and Crowley, J. N.: Rate coefficients for reaction of $\mathrm{OH}$ with Acetone between 202 and 395 K, J. Phys. Chem. A, 104, 2695-2705, 2000. 